\title{
A Study on the Painful Transition of Adolescent in J. D. Salinger's Writing
}

\author{
Xiaomei Han \\ School of Foreign Languages, Qinghai University for Nationalities, Xining, China
}

\begin{abstract}
Jerome David Salinger served as a spokesman for the alienated American adolescent, in The Catcher in the Rye, Holden represented the adolescent who experienced a painful transition from childhood into adulthood. After experiencing the fall of idealism and a series of symbolic death, he finally found his place in the adult world. Holden represents a lasting symbol of restless American youth.
\end{abstract}

Index Terms - transition, adolescent, Salinger

The adolescence means to grow up into maturity. Adolescence is a transitional period from childhood into adulthood that includes "... an ending and a beginning, a departure and arrival, a death and rebirth, a meeting of past and future." (Rogers, 1985, p.7) Usually this special period tends to cause kind of "identity crisis". An adolescence psychologist ever notes, "Not until adolescence does the individual develop the prerequisites in physiological growth, mental maturation and social responsibility to experience and pass through the crisis of identity." (Erikson, 1968, p.91)

Jerome David Salinger is one of the most influential writers In American literature. He represents as a spokesman for the alienated American youth. The Catcher in the Rye inevitably stands out as the first and only novel of Salinger. The whole novel shows Holden's transition from childhood into adulthood, a process of painful. After experiencing the fall of idealism and a series of symbolic death, he finally found his place in the adult world.

\section{THE FAIL OF IDEALISM}

This novel is about the two-and-half-day adventure of a dropout Holden, which vividly reflects a lonely alienated and bitter sense of the young Americans in the post-war period. As an adolescent, he experiences the painful transition from childhood to adulthood, which is a special and critical phrase in a person's life. Holden belongs to neither of child and adult worlds. In the end his choice is to be neither immature nor the evil of adulthood. He is put in a dilemma. As an adolescent, Holden actually searches for idealism, sincerity, and decency. However, his actions and thoughts meet with naked rejection by many who would cry with one voice, "Holden, why don't you just grow up?" In fact, Holden represents the uniqueness in man in a world which has lost its spirit for the idealism.

In the novel Holden is usually against both the materialism and ugliness of our society or against the realities of the adult world. Holden's only real friend, his sister Phoebe, complains that Holden doesn't like anything that's happening. But actually he does not take a very satisfactory action because he lacks any real positive program for eradicating the evils he finds all around him. But he is like a searcher for idealism-a striving to find the good and the perfection in man.

No doubt it would not be different to understand the phonies, the bores, and the deceivers whom Holden so dislikes. They actually "constitute a fair average" of what the culture affords. They are part of the truth which Holden doesn't see, is never able to see, or in fact refuse to see. The phonies, the bores, and the deceivers are one part of humanity. It is the reality that everyone must accept. And perhaps this is the main reason that Holden's search for idealism is finally broken.

Many adults feel that adolescent should "grow up", accept the world for what it is, and live in it. In essence, throw off any ideas of ever reaching for or becoming a part of an ideal world. At first notice, this is a sound but conservative recommendation. However, taken seriously and logically, the advice would put an end to any search for idealism, sincerity, and decency. There are some adolescents who are simply not like the majority, who cannot accept the human condition for what it is, who cannot resign themselves to the existence of injustice, ugliness, and pain. This refusal to accept the status quo in the world marks not only the adolescents---it also marks many adults who may be seen as an adolescent who has refused to "grow up", who is unable or unwilling to cover his inner life with the calluses necessary for the ordinary life. These individuals wage war with the-way-things-are. They are martyrs in the eternal search for idealism.

It is important to protect and cherish the uniqueness of the adolescent who, rightly or wrongly, refuses to accept completely the existing reality of the adult world. Holden, like most adolescents, is on the way to search for his true self and his place in the world. But the adolescent's disillusionment and sense of failure would arrive when he fails in his search for an ideal and decent world for his ideal and decent self.

A great part of the adolescent's idealism probably stems from his resistance to growing up. Still, it is rather difficult to criticize this resistance to entering a world lacking in the ideals found within the spirit of the young adolescent. 
Holden's distaste for his findings, in his collision with the outside world, seems to be warranted. If this be true, one should recognize the adolescent's need for viewing and experiencing himself from the inside-exploring his inner life where idealism is free to live and flourish. As reality closes in on the adolescent, he fights all the harder to escape it and preserve his self-made paradise.

Adolescent idealism is found in Holden's quest for sincerity, for honesty between people. His repeated insistence, "I mean it, I really do," gives credence to this search. And when Holden does experience decency, as he does with his sister Phoebe, he reacts decently to it. Holden, as many adolescents, is extremely sensitive to the god and evil in society. He may often be criticized for being too sensitive about the realities of society to live in it. Perhaps the adolescents is too sensitive to ignore it, to look the other way, to withdraw, as the so-called well-adjusted and busy adults withdraw into their protective shells when they face with society's terrors and ugliness. Holden simply cannot accept the injustices and ugliness that surround him. But he can meet them head-on. It is to the adolescent's great credit that, in spite of numerous disillusionments, he believes that there must be sincerity somewhere among the world. As long as the adolescent can hold on to the conviction that there are external counterparts to his ideal self, he can keep going. When this vision of his self-made society is finally broken in his encounter with the world of reality, the adolescent must compromise or painfully withdraw from the world of reality.

The idealistic rebellion of adolescent is a good thing when it is harnessed to idealistic even though unworkable in the hard world of reality. There must be some virtue in rebellion against a false, lying, and deceitful society. Most adolescents eventually come to terms with things as they are. They give up their idealistic ideas of working any radical changes in the social structure or in the culture's value system. They try at least, painful as it may be to find their own "realistic" place in society. Holden was unable to do this very thing. So he is both intensely praised and violently condemned.

\section{The Symbolic Death in the Process of MAturing}

Anthropologists believe that the acquisition of knowledge occurs in the compulsory social rite, but through the acquirer himself and once he gets knowledge he must convert it into action. Adolescence is a major period to gain knowledge. Therefore, adolescents must leave their familiar community and experience many things by themself. In this process symbolic death plays an important role in adolescents' maturing. In the novel Holden decides to leave Pencey Prep School on Wednesday suddenly. In fact, this is the beginning of his maturing journey, but his sudden decision to leave school is just caused by a specific incident which driving him almost crazy.

The specific incident is that he finds Stradlater is dating Jane. What horrifies him mostly is the discovery that Stradlater even doesn't know her name. This is the classic symbol of the loss of identity. For Stradlater, Jane is not a live human being, but a lifeless object to satisfy his personal desires.

But at that time Holden can't protect Jane, even himself being knocked out with blood. In the process of maturing, blood can be regarded as a symbol of growth. This is the first time for Holden to experience symbolic death. He is pushed out of the paradise of childhood heavily and enters the world of adult unwillingly. At that moment, the strong desire pushes him to leave school immediately. Holden wants to search for another holy world without Stradlater and his fellow Penceyans.

An important stage of the maturing is to search for a holy place, where adolescent can get the essential knowledge of adult. Holden's final destination is New York City where various phony people are gathered. For Holden New York is familiar but also strange. It is familiar because his family is there. He knows it very well and he is sure not to be lost there. But at the same time, it is strange for him too, because Holden only know the external appearance of the city well, but not the internal complicated society. Thus it is doomed that in Holden's adventure he must go through a series of severe tests.

A heroine needed to mention here is Jane Gallagher, the girl Stradlater is dating with, She is the only person Holden ever showed Allie's baseball glove. So Holden would rather Allie be more pure and close with him when he is depressed deeply and near to his own death. After he departs the wicker bar, he thinks, "I might have died of pneumonia, I began to imagine the millions bastard come to my funeral." (Salinger, 1951, p.154)

In the growth stage adolescent must confront the threat of death. As the representative of adolescents, Holden, seriously influenced by his younger brother Allie's death, can never get away from the thoughts of death. Allie's memory is persevered forever in death.

Holden experienced his second symbolic death when he leaves for New York at midnight. Holden quarrels with Maurice, a pimp, for additional five dollars. To Holden, the argument is not only concerned on money but his principle. He can't stand for cheat and falsehood. However, Holden seemed so weak when he confronts the adult world which is full of deceives and violence. When he is at school, fighting with Stradlater, he thinks at least he can deal with him. But this time, he faces a sophisticated guy in the aggressive and dirty society. Holden can only cry helplessly under the attack of such a powerful opponent. At the end, Maurice takes five dollars from Holden's wallet and goes away. "I stayed on the floor a fairly long time... I thought I was dying. I really did. I thought I was drowning or something. The trouble was, I could hardly breathe." (Salinger, 1951, p.103)

This is the second time Holden experiences the symbolic death, and he thinks about it solemnly. Even after a bath he still can't calm down. Pure water couldn't clean away his sadness and depression. The incident even drives Holden to 
be crazy. "What I really felt like, though, was committing suicide. I felt like jumping out the window." (Salinger, 1951, p.104)

The third time Holden is haunted by symbolic death when he wanders in the museum to kill time before he meets Phoebe. The quite mummy rooms of the museum makes Holden feel restful and comfortable. Holden really enjoys this rare peacefulness and harmony. He thinks: "I am sort of liked it, in a way. It was so nice and peaceful." (Salinger, 1951, p.204)

But this peaceful scene is disturbed suddenly by an obscene graffiti. Holden feels disappointed thoroughly. Even the museum, the last harmonious place, can't avoid the invasion of the messy and dirty outside world. "That's the whole trouble. You can't ever find a place that's nice and perfect, because there isn't any." (Salinger, 1951, p.204)So this temporary children's paradise collapses suddenly. Even though Holden loves niceness and purity, he can't break away from the evil and ugliness of the society. He has no other choice but to enter adulthood. In this sense he really needs a symbolic death as a child and a rebirth as an adult.

At this time Holden experiences his third symbolic death. He falls to the floor of the toilet as he feels sick. It is the fall that symbolizes Holden's transition from childhood into adulthood. Holden mentions. "I was lucky, though. I mean I could've killed myself when I hit the floor, but all I did was sort of land on my side. It was a funny thing. I felt better after I passed out." (Salinger, 1951, p.204)

After that experience Holden met his sister Phoebe. When Holden saw Phoebe riding the horse in the carrousel, he suddenly realizes his duty is to protect his sister. He knows although they play very well, the carrousel will stop; Phoebe will have to return to the real world. Although there is not a paradise of childhood in this world, these few minutes are happy time to them. As Holden watches his sister on the carousel in the rain, he achieves a state of ecstasy and enlightenment. He can only say: "It was just that she looked so dame nice, the way she kept going around and around in her blue coat and all. God, I wish you could've been there." (Salinger, 1951, p.213) Donald Barr defines such moments in Salinger's novel as "mystical glimpsing of God behind the identifier of the world." (Barr, 1962, p. 175) Holden has ended his search for identity and his efforts to affect the world by his own actions.

When Holden is watching Phoebe riding the carrousel, he utters: "God, I wish you could've been there." This is the first for him to admit the existence of God. Without the acknowledgement his transformation from childhood to adult would not be possible. Up to now, Holden completes his maturing process.

\section{THE CATCHER IN THE RYE}

Throughout the novel Holden even can't find a suitable place to stay. On his way to Old Spencer', he feels that he might disappear after going cross the street. Holden's strange thought reveals that he is actually afraid of advance, because he is not sure what is waiting for him ahead. He is afraid that he may be disappearing, or fall into misery. In fact, What Holden says and does here reflect the state he is in: he has nowhere to go; he cannot see where he is going in life; he will wander around aimlessly later in New York City, which is foreshadowed here. It implies a critical period in his life, which means the inevitable transition from adolescence to adulthood. The adult world is so repulsive, obscene and phony that he fears to enter into it. However, he cannot resist the process of growing up. Thus, he needs the proper guidance that will teach him how he will grow up and in what direction he should move. This is the difficulty Holden faces. There is nothing wrong with growing up according to Salinger. There is something wrong with growing phony.

However, Holden faces this difficulty with courage. In the middle of the book, his sister Phoebe asks him what would make him happy. He responds that he's picturing thousands of little children playing some game, but nobody's around. Holden himself is standing on the edge of the crazy cliff. What he has to do is to catch and protect every kid if they start to go over the cliff. He'd just like a catcher in the rye. That's the only thing he'd really like to be. "I thought it was if a body catches a body, I said, Anyway, I keep picturing all these little kids playing some game in this big field of rye and all. Thousands of little kids and nobody's around...except me. And I'm standing on the edge of some crazy cliff. What I have to do, I have to catch everybody if they start to go over the cliff---I mean if they're running and they don't look where they're going I have to come out from somewhere and catch them. That's all I'd do all day. I'd just be catcher in the rye and al. I know it's crazy, but that's the only thing I'd really like to be. I know it's crazy." (Salinger, 1951, p.224-225)

Actually it is a symbol that Holden wants to keep children from getting into trouble that comes with when they grow. But by the end of the book Holden finds that he cannot be the catcher because there must be many difficulties while one grows up. When critics consider the character of Holden Caulfield, many points to the novel's climatic scene: when Holden watches Phoebe ride the carousel in the rain his fantasy to protect the innocence of children is symbolically shattered.

Holden notices that there are only about five or six kids on the ride, and the song the carousel plays jazzily and funnily. All the kids keep trying to get for the gold ring, Holden is sort of afraid Phoebe might fall from the goddam horse, but he didn't say anything or do anything. He realizes that if the children want to grab for the gold ring, they should do it. It is not good to say any words to them. So, Phoebe gets on the carrousel, and Holden just watches her! When Phoebe invites him to join her in the riding, he says he will "just watch" (Salinger, 1951, p.218). In fact, he emphasizes this three times in their dialogue. He does feel afraid that she might fall off when grabbing for the gold ring. Holden eventually gives up his desire to be the catcher in the rye, for he realizes by this point that is "bad" to keep a 
child in childhood. As he learned from watching Phoebe's anger wane with the passing of time and events Phoebe must be allowed to experience her world if her one-sided nature is to develop beyond its present state. It is "bad" to interrupt her movement forward, even though it will result in the eventual fall of her inexperienced, innocent spirit, for the only alternative to this process would be to keep her in the same state, unmoving, undeveloped. Thus, symbolically Holden has realized that his dream is unrealistic: he cannot keep kids from growing up and getting their own experiences. After all, falling off a horse is certainly less dangerous than falling off a cliff.

Therefore, Holden becomes capable of accepting the necessity for movement within a child's existence. This change within Holden's outlook is stunning illustrated at the end of the novel by the movements of Phoebe on the carrousel. As Phoebe rides upon the horse, her actions illustrate every one of these symbolic movements: she goes forward, a suggestion of her nature changing, but in a circular motion, which keeps her essentially in the same place; and, at the same time, the horse she sits on continues moving her up and down. As a result, all of these characteristic motions, with all of their opposite qualities, are harmoniously blended within the immediate moment for Holden's perception as he watches Phoebe on the carrousel riding her horse "around and around"

The carrousel serves as a symbol composed of a complexity of opposite qualities and tenuous ambiguities. As a result, the dilemma which Holden has faced is resolved, when he sits in the rain, he can accept the world as it is. Furthermore, as is revealed by his concluding response to Phoebe on the carrousel, the divisive aspects of his nature, his emotions and his intellect, are finally integrated. At the end of the novel Holden feels happy all of the sudden just like his sister Phoebe, His happiness has no clear reason, and the only source might be Phoebe's happiness.

By means of these seemingly simple statements, Holden reveals that his response at this moment is an aesthetic one: he "felt so damn happy" because "she looked so damn nice." An aesthetic response is, by nature, a blending of sense perception, emotion, and intellect. It is not dependent upon one's being conscious of a reason for responding so---as Holden says, "I don't know why." It is elicited only when one perceives something which gives pleasure to every aspect of his nature at the same moment---a pleasure manifested in this case when Holden, by simply watching Phoebe on the carrousel, feel "so damn happy" (Salinger, 1951, p.218).

Critics have noticed that at the end of the novel Holden begins to stand in the mental institution. On the final page, Holden says that he might tell them what he has done after he backs home, and how he gets sick and all. After he found a solution to his dilemma, Holden is now attempting to recover. One might conclude by stressing that Holden is talking, not to an analyst, but to "you", the reader. Holden's reason for doing so was established earlier by Mr. Antolini, when he describes for Holden "the kind of information that will be very, very dear to your heart" (Salinger, 1951, p.214). Mr. Antolini mentions that many men have been just as trouble morally and spiritual as Holden is just now. Holden can learn from them---- to face them happily

Holden entire novel showed the transition to adulthood from childhood, a painful process, even though the future is uncertain, he broke off the relationship with the deceased in the past that he accepted mature. Holden in his most triumphant moment has ended his story, beyond the world of the plight and disillusionments

The whole novel shows a painful transition of Holden from childhood into adulthood. Even though the future is uncertain, Holden bravely breaks off his severed ties with the dead past in order to accept maturity. At his most triumphant moment, Holden has ended his story beyond the world's woes and disillusionments. Therefore, he says, "nobody could do anything phony when they visited me. If anybody tried to do anything phony, they couldn't stay." (Salinger, 1951, p.205)

From the world of Holden Caulfield, we may get a touch of the social and cultural codes in American society at that time and become more aware of adolescent crisis even existing today. The Catcher in the Rye is commonly considered as an antisocial "Declaration of American Youth", in which the dissatisfaction with postwar American society of the lost adolescent is reflected, their loss and unease felt for the adult world is described, and their spiritual bewilderment is revealed.

Holden has become a lasting symbol of restless American youth. Today, Holden's nervous breakdown at the end of the novel seems absolutely contemporary in a society whose youth are as troubled, and yet as defiantly hopeful, as they have ever been before. Consequently, it would be hard to overestimate the importance of the contribution Salinger made to American culture when he decided to write a novel about this "crazy" neurotic boy who flunks out of the prep school, set out on a short but strange odyssey to avoid backing home to face his parents, and, as he does, learns basic experiences about life, loss, and self.

\section{REFERENCES}

[1] Bloom, Harold. (1990). Major Literary Characters: Holden Caulfield. New York: Chelsea House Publishers.

[2] Donald, Barr. (1962).Saints, Pilgrims and Artists. In Henry Anatole Grunwald (ed.), Salinger: A Critical and Personal Portrait. New York: Harper \& Row, 170-176.

[3] Dorothy, Rogers. (1985). Adolescence and Youth. New Jersey: Prentice Hall Inc.

[4] Erik H. Erikson. (1968). Identity: Youth and Crisis. New York: Norton Press.

[5] Hamilton, Ian. (1988). In Search of J. D. Salinger. London: Heinemann.

[6] Horton, Rod W. (1974). Backgrounds of American Literary Though (3rd edn). New Jersey: Prentice-Hall, Inc.

[7] Pinsker, Sanford. (1993). The Catcher in the Rye: Innocence Under Pressure. Boston: Twayne Publisher, Inc.

[8] Salinger, J.D. (1951). The Catcher in the Rye. Boston: Little, Brown. 
[9] Salzman, Jack. (ed.)(1991). New Essays on The Catcher in the Rye. Cambridge: Cambridge University Press.

Xiaomei Han was born in Jan. 5, 1978, in Qinghai, PR China. She got Ph.D. degree from Beijing Language and Culture University in 2011. The major field of study is English literature. Now she is an associate professor in Qinghai University for Nationalities. 